\title{
Libertarian Paternalism
}

\section{Citation}

Cass Sunstein \& Richard Thaler, Libertarian Paternalism, 93 Am. Econ. Rev. 175 (2003).

\section{Published Version}

http://www.aeaweb.org/articles.php?doi=10.1257/000282803321947001\&fnd=s

\section{Permanent link}

http://nrs.harvard.edu/urn-3:HUL.InstRepos:12876718

\section{Terms of Use}

This article was downloaded from Harvard University's DASH repository, and is made available under the terms and conditions applicable to Other Posted Material, as set forth at http:// nrs.harvard.edu/urn-3:HUL.InstRepos:dash.current.terms-of-use\#LAA

\section{Share Your Story}

The Harvard community has made this article openly available.

Please share how this access benefits you. Submit a story.

\section{Accessibility}




\title{
BEHAVIORAL ECONOMICS, PUBLIC POLICY, AND PATERNALISM ${ }^{\dagger}$
}

\section{Libertarian Paternalism}

\author{
By Richard H. Thaler and Cass R. Sunstein*
}

Many economists are libertarians and consider the term "paternalistic" to be derogatory. Most would think that the phrase libertarian paternalism is an oxymoron. The modest goal of this essay is to encourage economists to rethink their views on paternalism. We believe that the anti-paternalistic fervor expressed by many economists is based on a combination of a false assumption and at least two misconceptions. The false assumption is that people always (usually?) make choices that are in their best interest. This claim is either tautological, and therefore uninteresting, or testable. We claim that it is testable and false-indeed, obviously false.

The first misconception is that there are viable alternatives to paternalism. In many situations, some organization or agent must make a choice that will affect the choices of some other people. The point applies to both private and public actors. Consider the problem facing the director of a company cafeteria who discovers that the order in which food is arranged influences the choices people make. To simplify, consider three alternative strategies: (1) she could make choices that she thinks would make the customers best off; (2) she could make choices at random; or (3) she could maliciously choose those items that she thinks would make the customers as obese as possible. Option 1

\footnotetext{
${ }^{\dagger}$ Discussants: Robert E. Hall, Stanford University; Gary Becker, University of Chicago; Robert Barro, Harvard University.

* Thaler: Department of Economics and Behavioral Science, University of Chicago Graduate School of Business, 1101 E. 58th Street, Chicago, IL 60637 (e-mail: thaler@gsb.uchicago.edu); Sunstein: Law School and Department of Political Science, University of Chicago, 1111 E. 60th Street, Chicago, IL 60637 (e-mail: csunstei@ midway.uchicago.edu). We are grateful to Richard Epstein, Russ Fuller, Owen Lamont, Eric Posner, Richard Posner, and David Wilcox for valuable comments on a previous draft.
}

appears to be paternalistic, which it is, but would anyone advocate options 2 or 3 ?

The second misconception is that paternalism always involves coercion. As the cafeteria example illustrates, the choice of which order to present food items does not coerce anyone to do anything, yet one might prefer some orders to others on paternalistic grounds. Would many object to putting the fruit before the desserts at an elementary school cafeteria if the outcome were to increase the consumption ratio of apples to Twinkies? Is this question fundamentally different if the customers are adults? If no coercion is involved, we think that some types of paternalism should be acceptable to even the most ardent libertarian. We call such actions libertarian paternalism.

In our understanding, a policy counts as "paternalistic" if it is selected with the goal of influencing the choices of affected parties in a way that will make those parties better off. We intend "better off" to be measured as objectively as possible, and we clearly do not always equate revealed preference with welfare. That is, we emphasize the possibility that in some cases individuals make inferior choices, choices that they would change if they had complete information, unlimited cognitive abilities, and no lack of willpower. Once it is understood that some organizational decisions are inevitable, that a form of paternalism cannot be avoided, and that the alternatives to paternalism (such as choosing options to make people sick, obese, or generally worse off) are unattractive, we can abandon the less interesting question of whether to be paternalistic or not and turn to the more constructive question of how to choose among paternalistic options. ${ }^{1}$

\footnotetext{
${ }^{1}$ Readers interested in this topic should also consult Colin Camerer et al. (2001) for an illuminating discussion of related issues. That paper shares with the papers in this
} 


\section{Are Choices Rational?}

The presumption that individual choices should be free from interference is usually based on the assumption that people do a good job of making choices, or at least that they do a far better job than third parties could do. As far as we can tell, there is little empirical support for this claim. Research by psychologists and economists over the past three decades has raised questions about the rationality of the judgments and decisions that individuals make. People do not exhibit rational expectations, fail to make forecasts that are consistent with Bayes' rule, use heuristics that lead them to make systematic blunders, exhibit preference reversals (that is, they prefer $\mathrm{A}$ to $\mathrm{B}$ and $\mathrm{B}$ to $\mathrm{A}$ ) and make different choices depending on the wording of the problem (for many examples, see the two recent collections of papers by Daniel Kahneman and Amos Tversky [2000] and by Thomas Gilovich et al. [2002]). Furthermore, in the context of intertemporal choice, people exhibit dynamic inconsistency, valuing present consumption much more than future consumption. In other words, people have selfcontrol problems (see the other papers in this session [James Choi et al., 2003b; Ted O'Donoghue and Matthew Rabin, 2003] for details and references).

Many economists are skeptical of some of these findings, thinking that people may do a better job of choosing in the "real world" than they do in the laboratory. However, studies of actual choices for high stakes reveal many of the same problems. For example, the Surgeon General reports that 61 percent of Americans are either overweight or obese. Given the adverse effects obesity has on health, it is hard to claim that Americans are eating optimal diets.

Another illustration comes from the domain of savings behavior. Shlomo Benartzi and Thaler (2002) investigate how much investors like the portfolios they have selected in their defined-contribution savings plans. Employees volunteered to share their portfolio choices with the investigators (by bringing a copy of their

session the common goal of devising policies that help some agents who are making some mistake, while minimizing the costs imposed on others. most recent statement to the lab). They were then shown the probability distributions of expected retirement income for three investment portfolios just labeled A, B, and C. Unbeknownst to the subjects, the three portfolios were their own and portfolios mimicking the average and median choices of their fellow employees. The distributions of expected returns were computed using the software of Financial Engines, the financial information company founded by William Sharpe. On average, the subjects rated the average portfolio equally with their own portfolio, and they judged the median portfolio to be significantly more attractive than their own. Indeed, only 20 percent of the subjects preferred their own portfolio to the median portfolio. Apparently, people do not gain much by choosing investment portfolios for themselves.

\section{Is Paternalism Inevitable?}

As the cafeteria line example discussed above illustrates, planners are forced to make some design choices. A simple and important example is the selection of a "default option" to determine what happens if an agent fails to choose for himself. In a fully rational world such design choices would have little effect (at least in high-stakes situations) because agents would simply choose the best option for them regardless of the default. However, numerous experiments illustrate that there is a very strong "status quo" bias (see William Samuelson and Richard Zeckhauser, 1988; Kahneman et al., 1991). The existing arrangement, whether set out by private institutions or by government, tends to stick.

One illustration of this phenomenon comes from studies of automatic enrollment in 401(k) employee savings plans. Most 401(k) plans use an opt-in design. When employees first become eligible to participate in the $401(\mathrm{k})$ plan, they receive some plan information and an enrollment form that must be completed in order to join. Under the alternative of automatic enrollment, employees receive the same information but are told that unless they opt out, they will be enrolled in the plan (with some default options for savings rates and asset allocation). In companies that offer a "match" (the employer matches the employee's contributions accord- 
ing to some formula, often a 50-percent match up to some cap), most employees eventually do join the plan, but enrollments occur much sooner under automatic enrollment. For example, Brigitte Madrian and Dennis Shea (2001) found that initial enrollments jumped from 49 percent to 86 percent, and Choi et al. (2002) find similar results for other companies.

Should the adoption of automatic enrollment be considered paternalistic? And, if so, should it therefore be seen as a kind of officious meddling with employee preferences? We answer these questions yes and no respectively. If the employer thinks (correctly, we believe) that most employees would prefer to join the 401(k) plan if they took the time to think about it and did not lose the enrollment form, then by choosing automatic enrollment they are acting paternalistically. They are attempting to steer employees' choices in directions that will promote employees' welfare. But since no one is forced to do anything, we think this steering should be considered unobjectionable to libertarians. The employer must choose some set of rules, and either plan affects employees' choices. No law of nature says that, in the absence of an affirmative election by employees, zero percent of earnings will go into a retirement plan. Because both plans alter choices, neither one can be said, more than the other, to count as a form of objectionable meddling.

Quick-minded readers might be tempted to think that there is a way out of this dilemma. Employers could avoid choosing a default if they required employees to make a choice, either in or out. But some thought reveals that this is not at all a way out of the dilemma; rather, it is simply another option among many that the employer can elect. In fact, Choi et al. (2003a) find that this rule increases enrollments (relative to the opt-in rule) though by not as much as automatic enrollment. Furthermore, the very requirement that employees make a choice has a paternalistic element. Many employees do not want to have to make a choice (and would choose not to have to do so). Should employers really force them to choose?

Why, exactly, does the setting of defaults have such large effects? With respect to savings, the designated default plan apparently carries a certain legitimacy for many employees, perhaps because it seems to have resulted from some conscious thought about what makes most sense for most people. But there is a separate explanation, involving inertia. For any employee, a change from any status quo entails time and effort, and many people seem to prefer to avoid both of these, especially if they are prone to procrastination. When default rules are "sticky" and affect choices as a result, inertia might be the major reason.

For present purposes, the choice among these various explanations does not much matter. The point is only that paternalism, in the form of effects on individual choices, is often unavoidable. When paternalism seems absent, it is usually because the starting point appears so natural and obvious that its preference-shaping effects are invisible to most observers. But those effects are nonetheless there. Of course it is usually good not to block choices, and we do not mean to defend non-libertarian paternalism here. But in an important respect, the antipaternalistic position is incoherent.

\section{Beyond the Inevitable (but Still Libertarian)}

The inevitability of paternalism is most clear when the planner has to choose default rules. It is reasonable to ask whether the planner should go beyond the inevitable. Take the cafeteria example discussed above. Putting the fruit before the desserts is a fairly mild intervention. A more intrusive step would be to place the desserts in another location altogether, so that diners have to get up and get a dessert after they have finished the rest of their meal. This step raises the transactions costs of eating dessert, and according to a standard economic analysis the proposal is unattractive: it seems to make dessert-eaters worse off and no one better off. But once self-control costs are incorporated, we can see that some diners would prefer this arrangement, namely, those who would eat a dessert if it were put in front of them but would resist temptation if given a little help. To the extent that the dessert location is not hard to find, and no choice is forbidden, this approach meets libertarian muster.

In the domain of employee savings, Thaler and Benartzi (2003) have proposed a method of increasing contributions to $401(\mathrm{k})$ plans that also meets the libertarian test. Under this plan, 
called Save More Tomorrow, employees are invited to sign up for a program in which their contributions to the savings plan are increased annually whenever they get a raise. Once employees join the plan, they stay in until they opt out or reach the maximum savings rate in the plan. In the first company to use this plan, the employees who joined increased their savings rates from 3.5 percent to 11.6 percent in a little over two years (three raises). Very few of the employees who join the plan drop out. This is successful libertarian paternalism in action.

\section{How to Choose: The Toolbox of the Libertarian Paternalist}

How should sensible planners (a category we mean to include anyone who must design plans for others, from human-resource directors to bureaucrats to kings) choose among possible systems, given that some choice is necessary? We suggest two approaches to this problem.

If feasible, a comparison of possible rules should be done using a form of cost-benefit analysis. The goal of a cost-benefit study would be to measure the full ramifications of any design choice. To illustrate, take the example of automatic enrollment. Under automatic enrollment some employees will join the plan who otherwise would not. Presumably, some are made better off (especially if there is an employer match), but some may be made worse off (e.g., those who are highly liquidityconstrained). If the issue were just enrollment, we would guess that the gains would exceed the losses. We base this guess partly on revealed choices. Most employees do join the plan eventually, and very few who are automatically enrolled opt out when they figure out what has happened to them. We also judge that the costs of having too little saved up for retirement are typically greater than the costs of having saved too much.

In many cases, however, the planner will be unable to make a direct inquiry into welfare, either because too little information is available or because the costs of doing the analysis are not warranted. The committed anti-paternalist might say, in such cases, that people should simply be permitted to choose as they see fit. We hope that we have said enough to show why this response is unhelpful. What people choose often depends on the starting point, and hence the starting point cannot be selected by asking what people choose. In these circumstances, the libertarian paternalist would seek indirect proxies for welfare: methods that test whether one or another approach is welfare-promoting without relying on unreliable guesswork about that question. We suggest three possible methods.

First, the libertarian paternalist might select the approach that the majority would choose if explicit choices were required and revealed. Useful though it is, this market-mimicking approach raises its own problems. Perhaps the majority's choices would be insufficiently informed. Perhaps those choices, in fact, would not promote the majority's welfare. At least as a presumption, however, it makes sense to follow those choices if the planner knows what they would be. A deeper problem is that the majority's choices might themselves be a function of the starting point or the default rule. If so, the problem of circularity dooms the marketmimicking approach. But in some cases, at least, the majority is likely to go one way or the other regardless of the starting point; and to that extent, the market-mimicking strategy seems quite workable.

Second, the libertarian paternalist might select the approach that would force people to make their choices explicit. This approach might be chosen if the market-mimicking strategy fails, either because of the circularity problem or because the planner does not know which approach would in fact be chosen by the majority. We have seen the possibility of forced choices in the context of retirement plans; it would be easy to find other examples. Here too, however, there is a risk that the choices that are actually elicited will be inadequately informed or will not promote welfare. In the case of retirement plans, for example, forced choices have been found to produce higher participation rates than requiring opt-ins, but lower rates than requiring opt-outs. If it is likely that automatic enrollment is welfare-promoting, perhaps automatic enrollment should be preferred over forced choices. The only suggestion is that, where the social planner is unsure how to handle the welfare question, he might devise a strategy that requires people to choose.

Third, the libertarian paternalist might select the approach that minimizes the number of opt- 
outs. For example, very few employees opt out of the 401(k) plan when they are automatically enrolled, though many opt in under the standard enrollment procedure. This is an ex post inquiry into people's preferences, in contrast to the ex ante approach favored by the market-mimicking strategy. With those numbers, there is reason to think that automatic enrollment is better, if only because more people are sufficiently satisfied to leave it in place.

\section{Conclusion}

Our goal here has been to defend libertarian paternalism, an approach that preserves freedom of choice but that authorizes both private and public institutions to steer people in directions that will promote their welfare. Some kind of paternalism is likely whenever such institutions set out arrangements that will prevail unless people affirmatively choose otherwise. In these circumstances, the goal should be to avoid random, arbitrary, or harmful effects and to produce a situation that is likely to promote people's welfare, suitably defined.

\section{REFERENCES}

Benartzi, Shlomo and Thaler, Richard H. "How Much Is Investor Autonomy Worth?" Journal of Finance, August 2002, 57(4), pp. 1593-1616.

Camerer, Colin; Issacharoff, Samuel; Loewenstein, George; O'Donoghue, Ted and Rabin, Matthew. "Regulation for Conservatives: Behavioral Economics and the Case for Asymmetric Paternalism." Working paper, California Institute of Technology, 2001.

Choi, James; Laibson, David; Madrian, Brigitte C. and Metrick, Andrew. "Defined Contribution Pensions: Plan Rules, Participant Decisions, and the Path of Least Resistance," in James M. Poterba, ed., Tax policy and the economy, Vol. 16. Cambridge, MA: MIT Press, 2002, pp. 67-113.

. "Benign Paternalism and Active Decisions: A Natural Experiment." Working paper, University of Chicago, Graduate School of Business, 2003a.

- "Optimal Defaults." American Economic Review, May 2003b (Papers and Proceedings), 93(2), pp. 180-85.

Gilovich, Thomas; Griffin, Dale and Kahneman, Daniel, eds. Heuristics and biases: The psychology of intuitive judgment. Cambridge, U.K.: Cambridge University Press, 2002.

-Kahneman, Daniel; Knetsch, Jack L. and Thaler, Richard H. "The Endowment Effect, Loss Aversion, and Status Quo Bias." Journal of Economic Perspectives, Winter 1991, 5(1), pp. 193-206.

Kahneman, Daniel and Tversky, Amos, eds. Choices, values, and frames. Cambridge, U.K.: Cambridge University Press, 2000.

-Madrian, Brigitte and Shea, Dennis. "The Power of Suggestion: Inertia in 401(k) Participation and Savings Behavior." Quarterly Journal of Economics, November 2001, 116(4), pp. 1149-87.

O'Donoghue, Ted and Rabin, Matthew. "Studying Optimal Paternalism, Illustrated by a Model of Sin Taxes." American Economic Review, May 2003 (Papers and Proceedings), 93(2), pp. 186-91.

-Samuelson, William and Zeckhauser, Richard J. "Status Quo Bias in Decision Making." Journal of Risk and Uncertainty, March 1988, 1(1), pp. 7-59.

Thaler, Richard H. and Benartzi, Shlomo. "Save More Tomorrow: Using Behavioral Economics to Increase Employee Saving." Journal of Political Economy, 2003 (forthcoming). 


\section{This article has been cited by:}

1. Adam Oliver, Peter Ubel. 2014. Nudging the obese: a UK-US consideration. Health Economics, Policy and Law 9:03, 329-342. [CrossRef]

2. Rachel Croson, Nicolas Treich. 2014. Behavioral Environmental Economics: Promises and Challenges. Environmental and Resource Economics 58:3, 335-351. [CrossRef]

3. Brian Wansink, Pierre Chandon. 2014. Slim by design: Redirecting the accidental drivers of mindless overeating. Journal of Consumer Psychology 24:3, 413-431. [CrossRef]

4. Martin Binder. 2014. Should evolutionary economists embrace libertarian paternalism?. Journal of Evolutionary Economics 24, 515-539. [CrossRef]

5. J. L. Lusk. 2014. Are you smart enough to know what to eat? A critique of behavioural economics as justification for regulation. European Review of Agricultural Economics 41, 355-373. [CrossRef]

6. A. J. Trujillo, A. Glassman, L. K. Fleisher, D. Nair, D. Duran. 2014. Applying behavioural economics to health systems of low- and middle-income countries: what are policymakers' and practitioners' views?. Health Policy and Planning . [CrossRef]

7. WERNER D. KRISTJANPOLLER, JOSEPHINE E. OLSON. 2014. The effect of financial knowledge and demographic variables on passive and active investment in Chile's pension plan. Journal of Pension Economics and Finance 1-22. [CrossRef]

8. Syngjoo Choi, Shachar Kariv, Wieland Müller, Dan Silverman. 2014. Who Is (More) Rational?. American Economic Review 104:6, 1518-1550. [Abstract] [View PDF article] [PDF with links]

9. Bruce Kogut, Jordi Colomer, Mariano Belinky. 2014. Structural equality at the top of the corporation: Mandated quotas for women directors. Strategic Management Journal 35:6, 891-902. [CrossRef]

10. Mario J. Rizzo. 2014. James M. Buchanan: Through an Austrian window. The Review of Austrian Economics 27:2, 135-145. [CrossRef]

11. Joseph P. DeMarco, Paul J. Ford. 2014. Neuroethics and the Ethical Parity Principle. Neuroethics . [CrossRef]

12. Johannes Abeler, Anke Becker, Armin Falk. 2014. Representative evidence on lying costs. Journal of Public Economics 113, 96-104. [CrossRef]

13. Sofie Kragh Pedersen, Alexander K. Koch, Julia Nafziger. 2014. WHO WANTS PATERNALISM?. Bulletin of Economic Research n/a-n/a. [CrossRef]

14. Judith Clifton, Daniel Díaz-Fuentes, Marcos Fernández-Gutiérrez. 2014. The impact of socioeconomic background on satisfaction: evidence for policy-makers. Journal of Regulatory Economics . [CrossRef]

15. Leonhard K. Lades. 2014. Impulsive consumption and reflexive thought: Nudging ethical consumer behavior. Journal of Economic Psychology 41, 114-128. [CrossRef]

16. P. J. Liu, J. Wisdom, C. A. Roberto, L. J. Liu, P. A. Ubel. 2014. Using Behavioral Economics to Design More Effective Food Policies to Address Obesity. Applied Economic Perspectives and Policy 36:1, 6-24. [CrossRef]

17. Kerstin Roeder. 2014. Optimal taxes and pensions with myopic agents. Social Choice and Welfare 42:3, 597-618. [CrossRef]

18. J. L. Lusk, S. Marette, F. B. Norwood. 2014. The Paternalist Meets His Match. Applied Economic Perspectives and Policy 36:1, 61-108. [CrossRef]

19. David Blake, Tom Boardman. 2014. Spend More Today Safely: Using Behavioral Economics to Improve Retirement Expenditure Decisions With S PEED O ME T E R Plans. Risk Management and Insurance Review 17:1, 83-112. [CrossRef] 
20. James A. Howard, Rassoul YazdipourRetirement Planning: Contributions from the Field of Behavioral Finance and Economics 285-305. [CrossRef]

21. Hazel Bateman, Jeanette Deetlefs, Loretti I. Dobrescu, Ben R. Newell, Andreas Ortmann, Susan Thorp. 2014. Just Interested or Getting Involved? An Analysis of Superannuation Attitudes and Actions. Economic Record n/a-n/a. [CrossRef]

22. M. M. Galizzi. 2014. What Is Really Behavioral in Behavioral Health Policy? And Does It Work?. Applied Economic Perspectives and Policy 36:1, 25-60. [CrossRef]

23. Christopher Jeffords. 2014. Preference-directed regulation when ethical environmental policy choices are formed with limited information. Empirical Economics 46:2, 573-606. [CrossRef]

24. Rachel J Huang, Alexander Muermann, Larry Y Tzeng. 2014. Regret and Regulation. The Geneva Risk and Insurance Review 39:1, 65-89. [CrossRef]

25. Mitesh Kataria, M. Vittoria Levati, Matthias Uhl. 2014. Paternalism with hindsight: do protégés react consequentialistically to paternalism?. Social Choice and Welfare . [CrossRef]

26. M. KifmannMandatory Systems, Issues of 195-198. [CrossRef]

27. K. Gillingham, K. Palmer. 2014. Bridging the Energy Efficiency Gap: Policy Insights from Economic Theory and Empirical Evidence. Review of Environmental Economics and Policy 8:1, 18-38. [CrossRef]

28. Dominique Cappelletti, Luigi Mittone, Matteo Ploner. 2014. Are default contributions sticky? An experimental analysis of defaults in public goods provision. Journal of Economic Bebavior \& Organization . [CrossRef]

29. Ajay Aggarwal, Joanna Davies, Richard Sullivan. 2014. "Nudge" in the clinical consultation - an acceptable form of medical paternalism?. BMC Medical Etbics 15:1, 31. [CrossRef]

30. Deepak N. Patel, Craig Nossel, Eleanore Alexander, Derek Yach. 2013. Innovative Business Approaches for Incenting Health Promotion in Sub-Saharan Africa: Progress and Persisting Challenges. Progress in Cardiovascular Diseases 56:3, 356-362. [CrossRef]

31. John Beshears, James J. Choi, David Laibson, Brigitte C. Madrian. 2013. Simplification and saving. Journal of Economic Bebavior \& Organization 95, 130-145. [CrossRef]

32. J. Mehta. 2013. The discourse of bounded rationality in academic and policy arenas: pathologising the errant consumer. Cambridge Journal of Economics 37:6, 1243-1261. [CrossRef]

33. Ana Cordeiro Santos, João Rodrigues. 2013. Neoliberalism in the Laboratory? Experimental Economics on Markets and their Limits. New Political Economy 1-27. [CrossRef]

34. Mark D. Agee, Thomas D. Crocker. 2013. Operationalizing the capability approach to assessing wellbeing. The Journal of Socio-Economics 46, 80-86. [CrossRef]

35. N. Craig Smith, Daniel G. Goldstein, Eric J. Johnson. 2013. Choice Without Awareness: Ethical and Policy Implications of Defaults. Journal of Public Policy \& Marketing 32:2, 159-172. [CrossRef]

36. J. F. Samhouri, A. J. Haupt, P. S. Levin, J. S. Link, R. Shuford. 2013. Lessons learned from developing integrated ecosystem assessments to inform marine ecosystem-based management in the USA. ICES Journal of Marine Science . [CrossRef]

37. Zachary Brown, Nick Johnstone, Ivan Haščič, Laura Vong, Francis Barascud. 2013. Testing the effect of defaults on the thermostat settings of OECD employees. Energy Economics 39, 128-134. [CrossRef]

38. B. I. Carlin, S. Gervais, G. Manso. 2013. Libertarian Paternalism, Information Production, and Financial Decision Making. Review of Financial Studies 26:9, 2204-2228. [CrossRef]

39. Jörn S. Basel, Rolf Brühl. 2013. Rationality and dual process models of reasoning in managerial cognition and decision making. European Management Journal . [CrossRef] 
40. Richard Sadler, Jason Gilliland, Godwin Arku. 2013. A Food Retail-Based Intervention on Food Security and Consumption. International Journal of Environmental Research and Public Health 10:8, 3325-3346. [CrossRef]

41. Giuseppe Schiavone, Gabriele Anna, Matteo Mameli, Vincenzo Rebba, Giovanni Boniolo. 2013. Libertarian paternalism and health care policy: a deliberative proposal. Medicine, Health Care and Philosopby . [CrossRef]

42. Robert Sugden. 2013. The Behavioural Economist and the Social Planner: To Whom Should Behavioural Welfare Economics Be Addressed?. Inquiry 1-20. [CrossRef]

43. J. Flanigan. 2013. Public Bioethics. Public Health Etbics 6:2, 170-184. [CrossRef]

44. Jamie A. Tratalos, Robert Sugden, Ian J. Bateman, Jennifer A. Gill, Andy P. Jones, David A. Showler, William J. Sutherland, Andrew R. Watkinson. 2013. The Conflict Between Conservation and Recreation When Visitors Dislike Crowding: A Theoretical and Empirical Analysis of the Spatial Distribution of Recreational Beach Users. Environmental and Resource Economics 55:3, 447-465. [CrossRef]

45. Andrew Cruickshank, Dave Collins, Sue Minten. 2013. Culture Change in a Professional Sports Team: Shaping Environmental Contexts and Regulating Power. International Journal of Sports Science and Coaching 8:2, 271-290. [CrossRef]

46. CHRISTIAN SCHUBERT, CHRISTIAN CORDES. 2013. Role models that make you unhappy: light paternalism, social learning, and welfare. Journal of Institutional Economics 9:02, 131-159. [CrossRef]

47. Kazuki Onji. 2013. Estimating the effects of procrastination on performance: A small sample study. The Journal of Socio-Economics 44, 85-90. [CrossRef]

48. Miriam Krieger, Stefan Felder. 2013. Can Decision Biases Improve Insurance Outcomes? An Experiment on Status Quo Bias in Health Insurance Choice. International Journal of Environmental Research and Public Health 10:6, 2560-2577. [CrossRef]

49. Shlomo Cohen. 2013. Nudging and Informed Consent. The American Journal of Bioetbics 13:6, 3-11. [CrossRef]

50. Koichi Takeda, Toshihiko Takemura, Takashi Kozu. 2013. Investment Literacy and Individual Investor Biases: Survey Evidence in the Japanese Stock Market. The Review of Socionetwork Strategies 7:1, 31-42. [CrossRef]

51. Chen Li, Zhihua Li, Peter P. Wakker. 2013. If nudge cannot be applied: a litmus test of the readers' stance on paternalism. Theory and Decision . [CrossRef]

52. Magnus Dahlquist, José Vicente Martinez. 2013. Investor Inattention: A Hidden Cost of Choice in Pension Plans?. European Financial Management n/a-n/a. [CrossRef]

53. Braden K. Mogler, Suzanne B. Shu, Craig R. Fox, Noah J. Goldstein, Ronald G. Victor, José J. Escarce, Martin F. Shapiro. 2013. Using Insights From Behavioral Economics and Social Psychology to Help Patients Manage Chronic Diseases. Journal of General Internal Medicine 28:5, 711-718. [CrossRef]

54. David W Stewart. 2013. Reinventing Marketing and Public Policy for the Twenty-First Century: An Editorial Statement. Journal of Public Policy \& Marketing 32:1, 1-5. [CrossRef]

55. Andrew S. Hanks, David R. Just, Brian Wansink. 2013. Smarter Lunchrooms Can Address New School Lunchroom Guidelines and Childhood Obesity. The Journal of Pediatrics 162:4, 867-869. [CrossRef]

56. Adam Oliver. 2013. SHOULD BEHAVIOURAL ECONOMIC POLICY BE ANTIREGULATORY?. Health Economics 22:4, 373-375. [CrossRef] 
57. Joshua A. Weller, Nathan F. Dieckmann, Martin Tusler, C. K. Mertz, William J. Burns, Ellen Peters. 2013. Development and Testing of an Abbreviated Numeracy Scale: A Rasch Analysis Approach. Journal of Behavioral Decision Making 26:2, 198-212. [CrossRef]

58. P. Chandon. 2013. How Package Design and Packaged-based Marketing Claims Lead to Overeating. Applied Economic Perspectives and Policy 35:1, 7-31. [CrossRef]

59. Liam Delaney, Colm Harmon, Martin Ryan. 2013. The role of noncognitive traits in undergraduate study behaviours. Economics of Education Review 32, 181-195. [CrossRef]

60. Gilles Saint-Paul. 2013. Liberty and the Post-utilitarian Society. Economic Affairs 33:1, 119-126. [CrossRef]

61. Josef Kaenzig, Stefanie Lena Heinzle, Rolf Wüstenhagen. 2013. Whatever the customer wants, the customer gets? Exploring the gap between consumer preferences and default electricity products in Germany. Energy Policy 53, 311-322. [CrossRef]

62. Jim Leitzel. 2013. Toward Drug Control: Exclusion and Buyer Licensing. Criminal Law and Philosopby 7:1, 99-119. [CrossRef]

63. R.L. GordonCoal: Prospects in the Twenty-First Century: Exhaustion Trumped by Global Warming? 137-145. [CrossRef]

64. Stavros A. Drakopoulos, Ioannis Theodossiou. 2012. Workers' risk underestimation and occupational health and safety regulation. European Journal of Law and Economics . [CrossRef]

65. Christian Gross, Roland Königsgruber. 2012. What You Measure is What You Get: The Effects of Accounting Standards Effects Studies. Accounting in Europe 9:2, 171-190. [CrossRef]

66. Jennifer Prah Ruger. 2012. Global Health Justice and Governance. The American Journal of Bioetbics 12:12, 35-54. [CrossRef]

67. Jorge E. Araña, Carmelo J. León. 2012. Can Defaults Save the Climate? Evidence from a Field Experiment on Carbon Offsetting Programs. Environmental and Resource Economics . [CrossRef]

68. KENNETH GILLINGHAM, JAMES SWEENEY. 2012. BARRIERS TO IMPLEMENTING LOW-CARBON TECHNOLOGIES. Climate Change Economics 03:04, 1250019. [CrossRef]

69. Morris Altman. 2012. Implications of behavioural economics for financial literacy and public policy. The Journal of Socio-Economics 41:5, 677-690. [CrossRef]

70. Christopher P. Chambers, Takashi Hayashi. 2012. Choice and individual welfare. Journal of Economic Theory 147:5, 1818-1849. [CrossRef]

71. Erel Avineri. 2012. On the use and potential of behavioural economics from the perspective of transport and climate change. Journal of Transport Geography 24, 512-521. [CrossRef]

72. Fredrik Carlsson, Olof Johansson-Stenman. 2012. Behavioral Economics and Environmental Policy. Annual Review of Resource Economics 4:1, 75-99. [CrossRef]

73. Bruce Ian Carlin, David T. Robinson. 2012. What Does Financial Literacy Training Teach Us?. The Journal of Economic Education 43:3, 235-247. [CrossRef]

74. R. A. Skipper. 2012. Obesity: Towards a System of Libertarian Paternalistic Public Health Interventions. Public Health Ethics 5:2, 181-191. [CrossRef]

75. Stefan Mann, Miriam Gairing. 2012. Does Libertarian Paternalism Reconcile Merit Goods Theory with Mainstream Economics?. Forum for Social Economics 41:2-3, 206-219. [CrossRef]

76. Sendhil Mullainathan, Joshua Schwartzstein, William J. Congdon. 2012. A Reduced-Form Approach to Behavioral Public Finance. Annual Review of Economics 4:1, 511-540. [CrossRef]

77. Bruce Ian Carlin,, David T. Robinson. 2012. Financial Education and Timely Decision Support: Lessons from Junior Achievement. American Economic Review 102:3, 305-308. [Abstract] [View PDF article] [PDF with links] 
78. Joan Costa Font, Azusa Sato. 2012. Health systems futures: The challenges of technology, prevention and insurance. Futures. [CrossRef]

79. Jose-Luis Pinto-Prades, Jose-Maria Abellan-Perpiñan. 2012. When normative and descriptive diverge: how to bridge the difference. Social Choice and Welfare . [CrossRef]

80. Till Grüne-Yanoff. 2012. Old wine in new casks: libertarian paternalism still violates liberal principles. Social Choice and Welfare . [CrossRef]

81. Rik Crutzen, Dianne Cyr, Nanne K de Vries. 2012. The Role of User Control in Adherence to and Knowledge Gained from a Website: Randomized Comparison Between a Tunneled Version and a Freedom-of-Choice Version. Journal of Medical Internet Research 14:2, e45. [CrossRef]

82. Erik Angner, George LoewensteinBehavioral Economics 641-689. [CrossRef]

83. Greg J. Duncan. 2012. Give Us This Day Our Daily Breadth. Child Development 83:1, 6-15. [CrossRef]

84. H. SchmidtPublic Health Ethics 685-695. [CrossRef]

85. Mozaffar Qizilbash. 2011. Informed desire and the ambitions of libertarian paternalism. Social Choice and Welfare . [CrossRef]

86. Patricio S. Dalton, Sayantan Ghosal. 2011. Decisions with endogenous frames. Social Choice and Welfare . [CrossRef]

87. Kazuki Onji, Rina Kikuchi. 2011. Procrastination, prompts, and preferences: Evidence from daily records of self-directed learning activities. The Journal of Socio-Economics 40:6, 929-941. [CrossRef]

88. Jan Schnellenbach. 2011. Nudges and norms: On the political economy of soft paternalism. European Journal of Political Economy . [CrossRef]

89. Christian Schubert. 2011. Is novelty always a good thing? Towards an evolutionary welfare economics. Journal of Evolutionary Economics . [CrossRef]

90. Julie Richardson AgnewPension Participant Behavior 577-594. [CrossRef]

91. J. Costa-Font. 2011. Behavioural Welfare Economics: Does 'Behavioural Optimality' Matter?. CESifo Economic Studies . [CrossRef]

92. Evan Selinger, Kyle Whyte. 2011. Is There a Right Way to Nudge? The Practice and Ethics of Choice Architecture. Sociology Compass 5:10, 923-935. [CrossRef]

93. Taejun Lee, Wonjun Chung, Eric Haley. 2011. Adherence of Retirement Mutual Fund Providers to the Securities and Exchange Commission (SEC)'s Advertising Guidance: Provision and Readability of Advertising Disclosure. Journal of Consumer Policy . [CrossRef]

94. Alexia Gaudeul, Robert Sugden. 2011. Spurious Complexity and Common Standards in Markets for Consumer Goods. Economica n/a-n/a. [CrossRef]

95. Li Way Lee. 2011. Behavioral bioethics: Notes of a behavioral economist. The Journal of SocioEconomics 40:4, 368-372. [CrossRef]

96. Pierre Pestieau, Gregory Ponthiere. 2011. Myopia, regrets, and risky behaviors. International Tax and Public Finance . [CrossRef]

97. Helmuth Cremer, Philippe De Donder, Darío Maldonado, Pierre Pestieau. 2011. Taxing Sin Goods and Subsidizing Health Care*. The Scandinavian Journal of Economics no-no. [CrossRef]

98. Åsa Löfgren, Peter Martinsson, Magnus Hennlock, Thomas Sterner. 2011. Are experienced people affected by a pre-set default option-Results from a field experiment. Journal of Environmental Economics and Management. [CrossRef]

99. Niclas Berggren. 2011. Time for behavioral political economy? An analysis of articles in behavioral economics. The Review of Austrian Economics . [CrossRef] 
100. Sabine Frerichs. 2011. False Promises? A Sociological Critique of the Behavioural Turn in Law and Economics. Journal of Consumer Policy . [CrossRef]

101. Adelle X. Yang, Christopher K. Hsee, Yi Liu, Li Zhang. 2011. The supremacy of singular subjectivity: Improving decision quality by removing objective specifications and direct comparisons. Journal of Consumer Psychology . [CrossRef]

102. GORDON L. CLARK. 2011. From Corporatism to Public Utilities: Workplace Pensions in the 21st Century. Geographical Research no-no. [CrossRef]

103. Jessica Pykett, Rhys Jones, Mark Whitehead, Margo Huxley, Kendra Strauss, Nick Gill, Kate McGeevor, Lee Thompson, Janet Newman. 2011. Interventions in the political geography of 'libertarian paternalism'. Political Geography . [CrossRef]

104. P. S. Dalton, S. Ghosal. 2011. Behavioral Decisions and Policy. CESifo Economic Studies . [CrossRef]

105. Gerrit AntonidesBehavioural Economics Applied 500-524. [CrossRef]

106. B. I. Carlin, G. Manso. 2011. Obfuscation, Learning, and the Evolution of Investor Sophistication. Review of Financial Studies 24:3, 754-785. [CrossRef]

107. A. C. Santos. 2011. Behavioural and experimental economics: are they really transforming economics?. Cambridge Journal of Economics . [CrossRef]

108. Trudy Ann Cameron, J.R. DeShazo, Erica H. Johnson. 2011. Scenario adjustment in stated preference research. Journal of Choice Modelling 4:1, 9-43. [CrossRef]

109. Gurley-Calvez. 2011. Choice in Public Health Insurance: Evidence from West Virginia Medicaid Redesign. Excellus Health Plan Inc . [CrossRef]

110. Paul Heidhues,, Botond Kőszegi. 2010. Exploiting Nä̈vete about Self-Control in the Credit Market. American Economic Review 100:5, 2279-2303. [Abstract] [View PDF article] [PDF with links]

111. Don Ross. 2010. Should the financial crisis inspire normative revision?. Journal of Economic Methodology 17:4, 399-418. [CrossRef]

112. Evan Selinger, Kyle Powys Whyte. 2010. Competence and Trust in Choice Architecture. Knowledge, Technology \& Policy 23:3-4, 461-482. [CrossRef]

113. Morris Altman. 2010. Freedom to Choose and Choice X-inefficiencies: Human and Consumer Rights, and Positive and Normative Implications of Choice Behavior. Review of Social Economy 68:4, 395-411. [CrossRef]

114. Daniel M. Hausman. 2010. HEDONISM AND WELFARE ECONOMICS. Economics and Philosopby 26:03, 321-344. [CrossRef]

115. Deirdre Shaw, Iain Black. 2010. Market based political action: a path to sustainable development?. Sustainable Development 18:6, 385-397. [CrossRef]

116. Thomas Rice, Yaniv Hanoch, Janet Cummings. 2010. What factors influence seniors' desire for choice among health insurance options? Survey results on the Medicare prescription drug benefit. Health Economics, Policy and Law 5:04, 437-457. [CrossRef]

117. Luca Zarri. 2010. Behavioral economics has two 'souls': Do they both depart from economic rationality?. The Journal of Socio-Economics 39:5, 562-567. [CrossRef]

118. Richard E. Just. 2010. Behavior, Robustness, and Sufficient Statistics in Welfare Measurement. Annual Review of Resource Economics 3:1, 110301102409075. [CrossRef]

119. Marta P. Coelho. 2010. Unrealistic Optimism: Still a Neglected Trait. Journal of Business and Psychology 25:3, 397-408. [CrossRef]

120. Markus Haavio, Kaisa Kotakorpi. 2010. The political economy of sin taxes. European Economic Review . [CrossRef] 
121. Pierre Combris. 2010. Comprendre et maîtriser l'évolution de l'alimentation : que faut-il attendre des économistes ?. Cabiers de Nutrition et de Diététique 45:3, 104-113. [CrossRef]

122. Cameron Hepburn, Stephen Duncan, Antonis Papachristodoulou. 2010. Behavioural Economics, Hyperbolic Discounting and Environmental Policy. Environmental and Resource Economics 46:2, 189-206. [CrossRef]

123. Gordon L. Clark. 2010. HUMAN NATURE, THE ENVIRONMENT, AND BEHAVIOUR: EXPLAINING THE SCOPE AND GEOGRAPHICAL SCALE OF FINANCIAL DECISIONMAKING. Geografiska Annaler: Series B, Human Geography 92:2, 159-173. [CrossRef]

124. C. Hepburn. 2010. Environmental policy, government, and the market. Oxford Review of Economic Policy 26:2, 117-136. [CrossRef]

125. Pavel Pelikán. 2010. The Government Economic Agenda in a Society of Unequally Rational Individuals. Kyklos 63:2, 231-255. [CrossRef]

126. Nicholas Stern. 2010. PRESIDENTIAL ADDRESS IMPERFECTIONS IN THE ECONOMICS OF PUBLIC POLICY, IMPERFECTIONS IN MARKETS, AND CLIMATE CHANGE. Journal of the European Economic Association 8:2-3, 253-288. [CrossRef]

127. Jessica Wisdom,, Julie S. Downs, George Loewenstein. 2010. Promoting Healthy Choices: Information versus Convenience. American Economic Journal: Applied Economics 2:2, 164-178. [Abstract] [View PDF article] [PDF with links]

128. Jonathan Baron. 2010. Nudge: Improving decisions about health, wealth, and happiness. Thaler, Richard H. \& Sunstein, Cass R. (Eds.), Yale University Press: New Haven, CT, 2008). Journal of Behavioral Decision Making 23:2, 224-226. [CrossRef]

129. David Leiser, Sacha Bourgeois-Gironde, Rinat Benita. 2010. Human foibles or systemic failureLay perceptions of the 2008-2009 financial crisis. The Journal of Socio-Economics 39:2, 132-141. [CrossRef]

130. Fabio Tufano. 2010. Are 'true' preferences revealed in repeated markets? An experimental demonstration of context-dependent valuations. Experimental Economics 13:1, 1-13. [CrossRef]

131. Corrado Di Maria, Susana Ferreira, Emiliya Lazarova. 2010. SHEDDING LIGHT ON THE LIGHT BULB PUZZLE: THE ROLE OF ATTITUDES AND PERCEPTIONS IN THE ADOPTION OF ENERGY EFFICIENT LIGHT BULBS. Scottish Journal of Political Economy 57:1, 48-67. [CrossRef]

132. Laurette DubéLibertarian Paternalism 435-441. [CrossRef]

133. Jonathan Baron. 2010. Cognitive biases in moral judgments that affect political behavior. Synthese 172:1, 7-35. [CrossRef]

134. Mario Hayek, Milorad M. Novicevic, John H. Humphreys, Nicole Jones. 2010. Ending the denial of slavery in management history: Paternalistic leadership of Joseph Emory Davis. Journal of Management History 16:3, 367-379. [CrossRef]

135. Dean Karlan, Jonathan MorduchAccess to Finance 4703-4784. [CrossRef]

136. David R. Just, Collin R. Payne. 2009. Obesity: Can Behavioral Economics Help?. Annals of Bebavioral Medicine 38:S1, 47-55. [CrossRef]

137. Robert Sugden. 2009. On Nudging: A Review of Nudge: Improving Decisions About Health, Wealth and Happiness by Richard H. Thaler and Cass R. Sunstein. International Journal of the Economics of Business 16:3, 365-373. [CrossRef]

138. Lei Delsen, Jeroen Smits. 2009. Does the Life Course Savings Scheme Have the Potential to Improve Work-Life Balance?. British Journal of Industrial Relations . [CrossRef]

139. LUIGI ZINGALES. 2009. The Future of Securities Regulation. Journal of Accounting Research 47:2, 391-425. [CrossRef] 
140. Shahzeen Z. Attari, Mary Schoen, Cliff I. Davidson, Michael L. DeKay, Wändi Bruine de Bruin, Robyn Dawes, Mitchell J. Small. 2009. Preferences for change: Do individuals prefer voluntary actions, soft regulations, or hard regulations to decrease fossil fuel consumption?. Ecological Economics 68:6, 1701-1710. [CrossRef]

141. T. Baldwin, R. Brownsword, H. Schmidt. 2009. Stewardship, Paternalism and Public Health: Further Thoughts. Public Health Ethics 2:1, 113-116. [CrossRef]

142. Kaisa Kotakorpi. 2009. Paternalism and Tax Competition. Scandinavian Journal of Economics 111:1, 125-149. [CrossRef]

143. Gordon L Clark, Pierre Pestieau. 2009. The 'new' paternalism, consultation and consent: Expectations of UK participants in defined contribution and self-directed retirement savings schemes. Pensions: An International Journal 14:1, 58-74. [CrossRef]

144. Robert Sugden. 2009. Market simulation and the provision of public goods: A non-paternalistic response to anomalies in environmental evaluation. Journal of Environmental Economics and Management 57:1, 87-103. [CrossRef]

145. Nathalie Moureau, Marion Vidal. 2009. Quand préférences déclarées et révélées s'opposent : le téléspectateur, un cas paradoxal pour l'économiste. Revue Française de Socio-Économie 4:2, 199. [CrossRef]

146. Lucie Davoine. 2009. L'économie du bonheur. Revue économique 60:4, 905. [CrossRef]

147. Valérie Clément, Nathalie Moureau, Marion Vidal. 2009. À la recherche des biens sous tutelle. L'Actualité économique 85:4, 383. [CrossRef]

148. Wilson Sy. 2009. Towards a national default option for low-cost superannuation. Accounting Research Journal 22:1, 46-67. [CrossRef]

149. Robert B. Talisse. 2009. Responses to My Critics. Transactions of the Charles S. Peirce Society 45:1, 90-108. [CrossRef]

150. Rebecca K. Ratner, Dilip Soman, Gal Zauberman, Dan Ariely, Ziv Carmon, Punam A. Keller, B. Kyu Kim, Fern Lin, Selin Malkoc, Deborah A. Small, Klaus Wertenbroch. 2008. How behavioral decision research can enhance consumer welfare: From freedom of choice to paternalistic intervention. Marketing Letters 19:3-4, 383-397. [CrossRef]

151. Simona Botti, Susan Broniarczyk, Gerald Häubl, Ron Hill, Yanliu Huang, Barbara Kahn, Praveen Kopalle, Donald Lehmann, Joe Urbany, Brian Wansink. 2008. Choice under restrictions. Marketing Letters 19:3-4, 183-199. [CrossRef]

152. Marcel Boumans. 2008. Battle in the Planning Office: Field Experts versus Normative Statisticians. Social Epistemology 22:4, 389-404. [CrossRef]

153. Sang Hoo Bae, Attiat F. Ott. 2008. The public economics of self control. Journal of Economics and Finance 32:4, 356-367. [CrossRef]

154. GORDON L. CLARK, KENDRA STRAUSS. 2008. Individual pension-related risk propensities: the effects of socio-demographic characteristics and a spousal pension entitlement on risk attitudes. Ageing \& Society 28:06. . [CrossRef]

155. Thomas Rice, Yaniv Hanoch. 2008. Can consumers have too much choice?. Expert Review of Pharmacoeconomics \& Outcomes Research 8:4, 325-327. [CrossRef]

156. J ASHTON, R HUDSON. 2008. Interest rate clustering in UK financial services markets\#. Journal of Banking \& Finance 32:7, 1393-1403. [CrossRef]

157. D BISHAI, J SINDELAR, E RICKETTS, S HUETTNER, L CORNELIUS, J LLOYD, J HAVENS, C LATKIN, S STRATHDEE. 2008. Willingness to pay for drug rehabilitation: Implications for cost recovery. Journal of Health Economics 27:4, 959-972. [CrossRef] 
158. JOHN KOZUP, JEANNE M. HOGARTH. 2008. Financial Literacy, Public Policy, and Consumers' Self-Protection-More Questions, Fewer Answers. Journal of Consumer Affairs 42:2, 127-136. [CrossRef]

159. Ian M. McDonald. 2008. Behavioural Economics. Australian Economic Review 41:2, 222-228. [CrossRef]

160. Jonathan Haidt, J. Patrick Seder, Selin Kesebir. 2008. Hive Psychology, Happiness, and Public Policy. The Journal of Legal Studies 37:S2, S133-S156. [CrossRef]

161. Ani Guerdjikova, Alexander Zimper. 2008. Flexibility of choice versus reduction of ambiguity. Social Choice and Welfare 30:3, 507-526. [CrossRef]

162. Ellen Peters. 2008. Numeracy and the Perception and Communication of Risk. Annals of the New York Academy of Sciences 1128:1, 1-7. [CrossRef]

163. Jody L. Sindelar. 2008. Paying for performance: the power of incentives over habits. Health Economics 17:4, 449-451. [CrossRef]

164. Daniel Pichert, Konstantinos V. Katsikopoulos. 2008. Green defaults: Information presentation and pro-environmental behaviour. Journal of Environmental Psychology 28:1, 63-73. [CrossRef]

165. JOHN KOZUP, ELIZABETH HOWLETT, MICHAEL PAGANO. 2008. The Effects of Summary Information on Consumer Perceptions of Mutual Fund Characteristics. Journal of Consumer Affairs 42:1, 37-59. [CrossRef]

166. O JOHANSSONSTENMAN. 2008. Mad cows, terrorism and junk food: Should public policy reflect perceived or objective risks?. Journal of Health Economics 27:2, 234-248. [CrossRef]

167. Christiaan Hogendorn, Paul KleindorferThe Economics of Renewable Resource Credits 167-190. [CrossRef]

168. Fredric Jacobsson, Magnus Johannesson, Lars Borgquist. 2007. Is Altruism Paternalistic?. The Economic Journal 117:520, 761-781. [CrossRef]

169. S. Holm. 2007. Obesity interventions and ethics. Obesity Reviews 8:s1, 207-210. [CrossRef]

170. Paul Dolan, Mathew P. White. 2007. How Can Measures of Subjective Well-Being Be Used to Inform Public Policy?. Perspectives on Psychological Science 2:1, 71-85. [CrossRef]

171. Nathan Berg, Gerd Gigerenzer. 2007. Psychology Implies Paternalism? Bounded Rationality may Reduce the Rationale to Regulate Risk-Taking. Social Choice and Welfare 28:2, 337-359. [CrossRef]

172. Jeffrey Friedman. 2007. IGNORANCE AS A STARTING POINT: FROM MODEST EPISTEMOLOGY TO REALISTIC POLITICAL THEORY. Critical Review 19:1, 1-22. [CrossRef]

173. Lester B. Lave, Jay Apt. 2006. Planning for natural disasters in a stochastic world. Journal of Risk and Uncertainty 33:1-2, 117-130. [CrossRef]

174. A ABADIE, S GAY. 2006. The impact of presumed consent legislation on cadaveric organ donation: A cross-country study. Journal of Health Economics 25:4, 599-620. [CrossRef]

175. Peter H. Sand. 2006. Labelling Genetically Modified Food: The Right to Know. Review of European Community and International Environmental Law 15:2, 185-192. [CrossRef]

176. Scott A. Beaulier, J. Robert Subrick. 2006. Poverty traps and the robust political economy of development assistance. The Review of Austrian Economics 19:2-3, 217-226. [CrossRef]

177. YANIV HANOCH, THOMAS RICE. 2006. Can Limiting Choice Increase Social Welfare? The Elderly and Health Insurance. The Milbank Quarterly 84:1, 37-73. [CrossRef]

178. C HSEE, R HASTIE. 2006. Decision and experience: why don't we choose what makes us happy?. Trends in Cognitive Sciences 10:1, 31-37. [CrossRef] 
179. Laura A. Costanzo, John K. Ashton. 2006. Product innovation and consumer choice in the UK financial services industry. Journal of Financial Regulation and Compliance 14:3, 285-303. [CrossRef]

180. Kevin D. McCaul, Ellen Peters, Wendy Nelson, Michael Stefanek. 2005. Linking Decision-Making Research and Cancer Prevention and Control: Important Themes. Health Psychology 24:4, Suppl, S106-S110. [CrossRef]

181. Jonathan Baron. 2004. Cognitive Biases, Cognitive Limits, and Risk Communication. Journal of Public Policy \& Marketing 23:1, 7-13. [CrossRef]

182. Richard H. Thaler, Shlomo Benartzi. 2004. Save More Tomorrow ${ }^{\mathrm{TM}}$ : Using Behavioral Economics to Increase Employee Saving. Journal of Political Economy 112:S1, S164-S187. [CrossRef]

183. Floris HeukelomBuilding and Defining Behavioral Economics 1-29. [CrossRef] 